\title{
Perencanaan Dinding Penahan Tanah Tipe Kantilever Dengan Menggunakan Program GEO5 (Studi Kasus : Jalan Komplek Kantor Bupati Kabupaten Sorong)
}

\author{
Sahril Achmad \\ Program Study Teknik Sipil Universitas Muhammadiyah Sorong \\ Jalan Pendidikan No 27 Kota Sorong, Propinsi Papua Barat \\ Email : sahriachmad19@gmail.com
}

\begin{abstract}
ABSTRAK
Kabupaten Sorong merupakan salah satu daerah yang cukup berkembang di Papua Barat. Perkembangan ini tentunya tidak lepas dari peran pemerintah dan masyarakatnya. Namun, hal yang harus diperhatikan dalam mengembangkan suatu daerah adalah infrastruktur yang baik.Salah satu infrasturktur yang sangat di butuhkan adalah jalan. Bila jalan yang ada di daerah tersebut dalam kondisi yang baik, tentunya akan berdampak baik pada pertumbuhan ekonominya. Namun pada kenyataannya, masih ada ruas jalan yang rusak pada daerah tersebut akibat keruntuhan tanah. Salah satu faktor yang menimbulkan terjadinya masalah tersebut adalah tidak adanya dinding penahan tanah pada lereng yang tidak stabil. Akibatnya jalan yang ada diatas lereng tersebut mengalami keruntuhan.Jalan yang terletak di komplek Kantor Bupati Kabupaten Sorong merupakan salah satu akses yang biasa dilewati oleh para pengendara untuk menuju ke kantor-kantor pemerintahan yang berada disekitarnya. Ruas jalan ini memiliki salah satu sisi yang berada tepat diatas lereng dengan kondisi jalan yang rusak pada sisi tersebut karena terjadinya keruntuhan tanah pada lereng.Salah satu cara untuk mengatasi terjadinya keruntuhan tanah pada lereng tersebut adalah membangun dinding penahan tanah. Pada kondisi ini peneliti ingin mencoba merencanakan dinding penahan tanah tipe kantilever pada lereng tersebut.
\end{abstract}

KATA KUNCI : dinding penahan tanah, kantilever, GEO5, Kabupaten Sorong 


\section{PENDAHULUAN}

\section{Latar Belakang}

Kabupaten Sorong merupakan salah satu daerah yang cukup berkembang di Papua Barat. Perkembangan ini tentunya tidak lepas dari peran pemerintah dan masyarakatnya. Namun, hal yang harus diperhatikan dalam mengembangkan suatu daerah adalah infrastruktur yang baik.

Salah satu infrasturktur yang sangat di butuhkan adalah jalan. Bila jalan yang ada di daerah tersebut dalam kondisi yang baik, tentunya akan berdampak baik pada pertumbuhan ekonominya. Namun pada kenyataannya, masih ada ruas jalan yang rusak pada daerah tersebut akibat keruntuhan tanah. Salah satu faktor yang menimbulkan terjadinya masalah tersebut adalah tidak adanya dinding penahan tanah pada lereng yang tidak stabil. Akibatnya jalan yang ada diatas lereng tersebut mengalami keruntuhan.

Jalan yang terletak di komplek Kantor Bupati Kabupaten Sorong merupakan salah satu akses yang biasa dilewati oleh para pengendara untuk menuju ke kantor-kantor pemerintahan yang berada disekitarnya. Ruas jalan ini memiliki salah satu sisi yang berada tepat diatas lereng dengan kondisi jalan yang rusak pada sisi tersebut karena terjadinya keruntuhan tanah pada lereng.

Salah satu cara untuk mengatasi terjadinya keruntuhan tanah pada lereng tersebut adalah membangun dinding penahan tanah. Pada kondisi ini peneliti ingin mencoba merencanakan dinding penahan tanah tipe kantilever pada lereng tersebut. Dengan kondisi lereng yang mempunyai tinggi lebih dari 4 meter, peneliti merasa bahwa dinding penahan tanah tipe kantilever merupakan solusi yang tepat untuk mengatasi masalah tersebut dan tentunya dengan perhitungan yang tepat juga.

Peneliti merasa bahwa perlu adanya perhitungan dengan menggunakan program. Saat ini teknologi terus berkembang pesat, salah satunya dalam bidang geoteknik. Sudah ada beberapa program yang biasa digunakan untuk membantu memecahkan berbagai permasalahan geoteknik. Pada kesempatan ini peneliti akan membahas tentang program yang sudah banyak diketahui oleh orang yaitu GEO5. Program GEO5 dibuat untuk membantu memecahkan berbagai permasalahan geoteknik dengan kecepatan dan meminimalisir kesalahan pada saat menghitung.

\section{Tujuan Penelitian}

1. Menganalisis gaya-gaya yang bekerja pada dinding penahan tanah tipe kantilever.

2. Merencanakan dimensi dinding penahan tanah tipe kantilever yang aman terhadap stabilitas penggeseran, penggulingan dan kapasitas dukung tanah dengan metode manual.

3. Merencanakan dimensi dinding penahan tanah tipe kantilever yang aman terhadap stabilitas penggeseran, penggulingan dan kapasitas dukung tanah dengan menggunakan program GEO5.

4. Merencanakan penulangan untuk dinding penahan tanah tipe kantilever.

\section{STATE OF THE ART}

Adapun penelitian terdahulu yang terkait dengan penelitian ini adalah sebagai berikut :

\section{Arya Nugraha (2013)}

Penelitian tentang Perencanaan Dinding Penahan Tanah Dengan Menggunakan Program Geo5 yang berada di Jalan Piyungan - Batas Gunung Kidul. Dari penelitian ini didapatkan hasil-hasil sebagai berikut :

1. Hasil Perhitungan manual :

a) faktor stabilitas terhadap geser $2,475>2$ (aman)

b) stabilitas terhadap guling 3,945>2 (aman)

c) keruntuhan kapaitas daya dukung 4,874>3 (aman)

2. Hasil perhitungan program Geo5:

a) stabilitas terhadap guling 2,01>2 (aman)

b) stabilitas terhadap geser 2,32>2 (aman)

c) keruntuhan kapasitas daya dukung 5,11>2 (aman) 


\section{Adi Prasetya (2014)}

Penelitian tentang Perencanaan Desain Dan Stabilitas Dinding Penahan Tanah Kantilever Menggunakan Program Geo5 di Jalan Piyungan - Batas Gunung Kidul. Dari penelitian ini didapatkan hasil-hasil sebagai berikut :

1. Hasil Perhitungan manual :

a) faktor stabilitas terhadap geser 2,475>2 (aman)

b) stabilitas terhadap guling 3,945>2 (aman)

c) keruntuhan kapaitas daya dukung 4,874>3 (aman)

2. Hasil perhitungan program Geo5 :

a) stabilitas terhadap guling 2,03>2 (aman)

b) stabilitas terhadap geser $2,37>2$ (aman)

c) keruntuhan kapasitas daya dukung 5,31>2 (aman)

\section{Hardini, I Ardi Ansyah (2018)}

Penelitian tentang Study Perbandingan Perhitungan Dinding Penahan Tanah Kantilever (Cantilever Wall) Menggunakan Program Geo5 Dan Perhitungan Rankine Dan Coulomb.

1. Hasil Perhitungan dengan Metode Rankine

- $\quad$ Stabilitas terhadap Geser 2,775 > 1,5 (Aman)

- Stabilitas terhadap Guling 4,16>2 (Aman)

- Keruntuhan Kapasitas Daya Dukung Tanah 4,49 > 2 (Aman)

2. Hasil Perhtungan dengan Metode Coulomb

- Stabilitas terhadap Geser 1,83>1,5 (Aman)

- Stabilitas terhadap Guling 4,12> 2 (Aman)

- Keruntuhan Kapasitas Daya Dukung Tanah 3,24 > 2 (Aman)

3. Hasil Perhitungan dengan Program Geo5

- $\quad$ Stabilitas terhadap Geser 2,90>1,50 (Aman)

- Stabilitas terhadap Guling 2,96> 2 (Aman)

- Keruntuhan Kapasitas Daya Dukung Tanah 3,68 > 2 (Aman)

\section{METODE}

\section{Tahapan Penelitian}

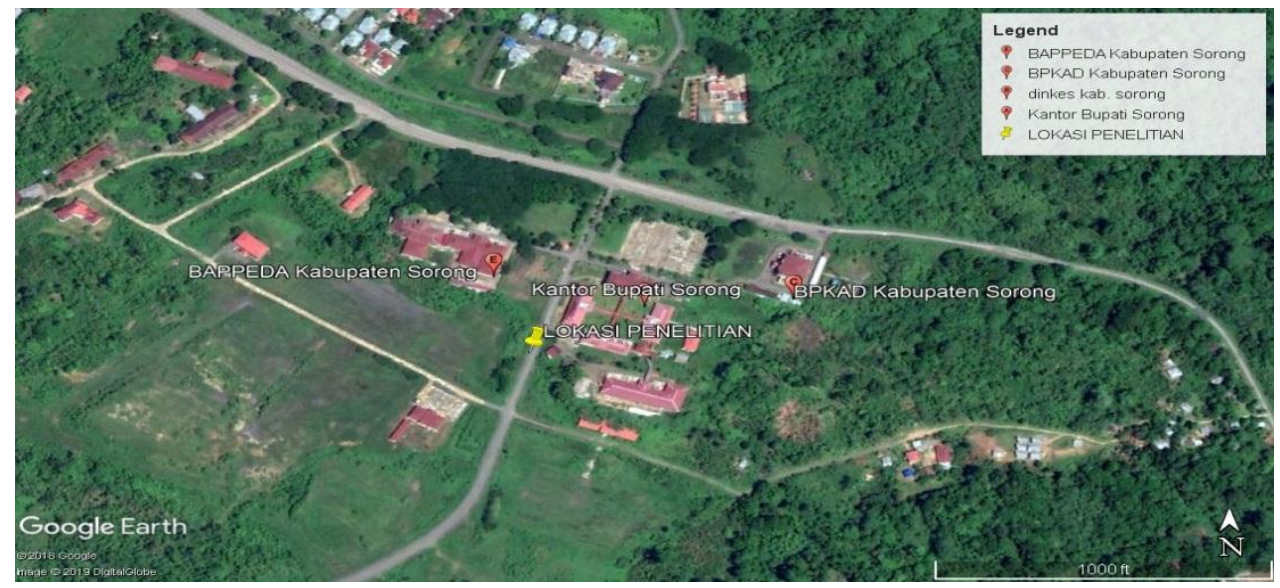

Tahapan dalam penelitian dibagi dalam beberapa tahap yaitu sebagai berikut:

a. Mengumpukan data-data tanah untuk perencanaan yaitu data lapangan dan data laboratorium sebagai perhitungan.

b. Menetapkan dimensi dinding vertikal, tebal dan lebar pelat pondasi pada dinding penahan tanah, serta menghitung beban dan reaksi tanah yang bekerja di atas dasar pondasi dinding penahan tanah.

c. Menghitung stabilitas dinding penahan tanah terhadap penggeseran, penggulingan serta daya dukung tanah dengan cara manual. 
d. Mengontrol faktor aman dinding penahan tanah terhadap penggeseran, penggulingan dan daya dukung tanah secara manual. Jika tidak sesuai dengan yang disyaratkan maka dilakukan perubahan dimensi dinding penahan tanah. Jika sudah sesuai dengan yang disyaratkan maka dapat melanjutkan ke tahap berikutnya.

e. Menganalisis stabilitas dinding penahan tanah dengan menggunakan program GEO5.

f. Setelah control stabilitas dinding penahan tanah menggunakan cara manual dan program GEO5 sudah sesuai dengan yang disyaratkan. Maka dapat direncanakan penulangannya.

g. Menarik kesimpulan dimensi yang akan digunakan, nilai stabilitas serta penulangan yang digunakan oleh dinding penahan tanah yang telah direncanakan.

\section{REFERENSI}

Arya Nugraha. (2013): Perencanaan Dinding Penahan Tanah Dengan Menggunakan Program Geo

Adi Prasetya. (2014): Perencanaan Desain Dan Stabilitas Dinding Penahan Tanah Kantilever Menggunakan Program Geo

Ardi Ansyah. (2018): Study Perbandingan Perhitungan Dinding Penahan Tanah Kantilever (Cantilever Wall) Menggunakan Program Geo5 Dan Perhitungan Rankine Dan Coulomb

Bowles, J. E. (1984): Physical and Geotechnical Properties of Soil Second Edition, Jakarta, Penerbit Erlangga

Bowles, J. E. (1986): Desain dan Analisa Pondasi. Jakarta, Penerbit Erlangga

Das, Braja M. (1990): Principles Of Foundation Engineering Second Edition, Boston, PWSKENT Publishing Company

Das, Braja M. (2010), Principles of Geotechnical Engineering First Edition, Sacramento. California State University

Hardiyatmo, H.C. (2010): Analisis dan Perancangan Fondasi 1, Yogyakarta, Gadjah Mada University Press

Hardiyatmo, H.C. (2010): Analisis dan Perancangan Fondasi 2, Yogyakarta, Gadjah Mada University Press

Hardiyatmo, H. C. (2003): Mekanika Tanah II, Edisi Ketiga, Yogyakarta, Gadjah Mada University Press

Hardiyatmo, H. C. (2003): Mekanika Tanah II, Edisi Ketiga, Yogyakarta, Gadjah Mada University Press

Das, Braja M. (2007). Principles of Foundation Engineering Sixth Edition. Chris Carson: United States.

Setiawan, Agus. (2016) Perancangan Struktur Beton Bertulang Berdasarkan SNI 2847:2013. Erlangga: Jakarta. 